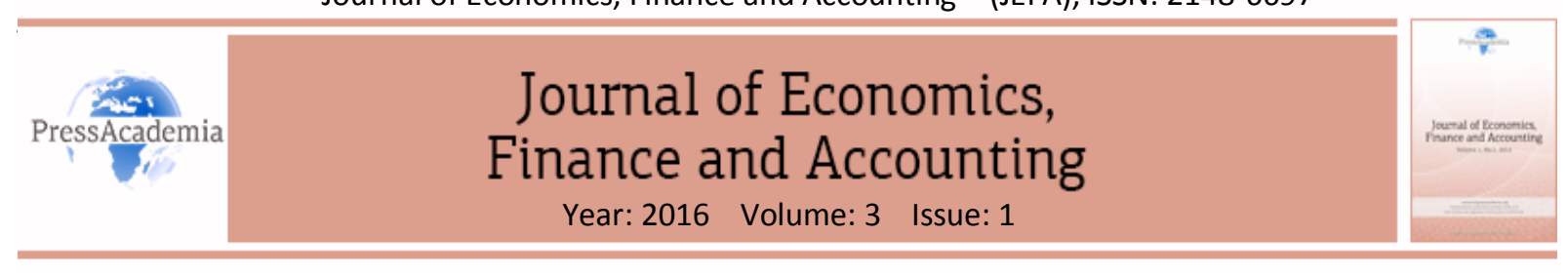

\title{
ANALYSING TURKISH INDIVIDUAL PENSION SYSTEM FEES AND RETURNS
}

\section{DOI: 10.17261/Pressacademia.2016116539}

\section{Ibrahim Peker}

Former CMB Executive Vice President, dribrahimpeker@gmail.com

\begin{abstract}
This study aims at categorizing, computing and analyzing fees and costs in Turkish Individual Pension System. To this end, net real returns after all costs were computed and these returns were compared with the disclosed fees and returns. Generally in practice, only fund management fees are taken into consideration for calculating net returns and with this method net annual average (geometric) return of the system is calculated as $2.01 \%$ for the 2008-2014 period. However, the results of this study show that when other "pension plan costs" are taken into account, net annual average return decreases to $0,19 \%$. The study also demonstrates that for generating $0.19 \%$ average net return, pension companies received 2.34\% fee on average in 2014. Thus, with this return and fee level, Turkish Individual Pension System Pis not sustainable without Government incentives.
\end{abstract}

Keywords : Turkish individual pension system, Turkish private pension funds, pension fees, pension returns, pension regulation. JEL Classification : G22, G23, G28

\section{TÜRKIYE BiREYSEL EMEKLiLIK SISTEMi ÜZERINDEKi KESINTILER ILE GETiRILERIN ANALizi}

\section{ÖZET}

Bu çalışma 2008-2014 yılları arasında Türkiye Bireysel Emeklilik sistemi üzerinde yer alan tüm gider kalemlerini sınıflandırmak, hesaplamak, analiz etmek ve çalışmada elde edilen verileri kullanarak giderlerden arındırılmış reel getirileri bulmak ve ortaya çıkan sonuçları, ilan edilmiş sonuçlarla karşılaştırmak amacıyla yapılmıştır. Giderlerden arındırılmış reel getiri hesaplamalarında genellikle sadece fon işletim gider kesintileri'nin dikkate alındığı, bu şekilde yapılan hesaplamalar sonucunda inceleme döneminde ortalama reel getirinin yıllık \% 2.01 olarak hesaplandığı, ancak reel getiri hesabında plan kapsamında yapılan diğer kesintiler'in de göz önüne alınması durumunda ortalama (geometrik) reel getirinin yıllık \% 0,19’a düştüğü sonucuna ulaşılmıştır. Sağlanan \% 0,19'luk ortalama reel getiri karşılığında ise, inceleme dönemi içerisinde en düşük toplam kesintinin gerçekleştiği 2014 yılında dahi \%2,34 oranındaki kesinti yapıldığı hesaplanarak, kamu desteği olmadan mevcut sistemin gider-getiri yapısının sürdürülemez olduğu sonucuna varılmıştır.

Anahtar Kelimeler: Bireysel emeklilik sistemi, BES, kesintiler, giderler, getiriler, bireysel emeklilik yatırım fonları JEL Sınıflandırılması: G22, G23, G28 


\section{GíRiş}

Bireysel emeklilik sisteminde 2013 yılından itibaren devlet katkısının uygulanması ile birlikte katılımcı sayısı 6 milyonu, Devlet katkı payı dahil olmak üzere yönetilen fon tutarı da 50 milyar TL'nı aşmıştır. Ancak katılımcı sayısında ve fon büyüklüğündeki artışa rağmen, getiril erin düşüklüğü karşısında kesintilerin yüksekliği, sistemin önündeki temel sorunlardan birisi olarak görülmeye başlanmış ve bu konudaki eleştiriler de artmaya başlamıştır.

Bireysel emeklilik planları ve emeklilik fonlarında uygulanan kesintiler, hem potansiyel katılımcılar için, hem de mevcut durumda sisteme dahil olup da, daha düşük kesinti uygulayan başka bir plana geçerek birikimlerini daha hızlı arttırmak isteyen mevcut katılımcılar için son derece önemli bir bilgi niteliğindedir. Zira emeklilik birikimlerinin artışında sağlanan portföy yönetim getirisi kadar, katkılar üzerinden yapılan kesintiler de önemlidir. Bu nedenle, hem emeklilik sistemi üzerindeki maliyetlerin ortaya çıkartılması, hem de maliyetlerin düşürülmesi ile ilgili bir çok uluslararası çalışma yapılmıştır. Özellikle son yıllarda bu konuda Whitehouse (2000), Turner (2005), Hernandez ve Stewart (2008), Pitt-Watson (2010), Bikker, Steenbeek ve Torracchi (2012), Ionescu ve Robles (2014), Tuesta (2014) ve Calveley (2015) tarafından çalışmalar yapılmış, farklı ülkelerin bireysel emeklilik sistemi üzerindeki maliyetler karşılaştırılmış, maliyetleri etkileyen faktörler incelenmiş ve maliyetleri düşürücü öneriler geliştirilmiştir.

Son dönemde, Türkiye'de bireysel emeklilik sisteminin getirilerinin az olması, sistemin kendi ürettiği getirilerden ziyade kamu katkısı ile varlığını sürdürmesi ve sistem üzerinden yapılan kesintilerin yüksekliğine ilişkin yapılan eleştiriler artmış olmakla birlikte, bu konuda bireysel emeklilik sistemi üzerindeki tüm giderleri dikkate alarak yapılan bir gider-getiri analizi mevcut değildir. Sistemde yer alan emeklilik planları ve emeklilik fonları ile ilgili tüm gider ve kesinti rakamlarını karşılaştırmalı olarak sunan ulaşılabilir bir veri seti olmadığından, bu konuda yapılan eleştiriler, yorumlar, hazırlanan raporlar ve çalışmalar da sadece açıklanan kesinti verilerine dayanılarak yapılmaktadır. Mevcut veri setleri genellikle sadece fon varlığı üzerinden yapılan kesintilere yer vermekte (fon toplam gider kesintisi ya da fon işletim gider kesintisi), katılım tutarları, emeklilik fonlarına yönlendirilmeden önce yapılan kesintiler ise (giriş aidatları, yönetim ve ara verme gider kesintileri) yapılan getiri hesaplamalarında dikkate alınamamakta, bu durum ise var olan giderlerin daha düşük, getirilerin ise daha yüksek olarak algılanmasına neden olmaktadır. Bu nedenle katılımcı sayısının 6 milyon kişiyi, Devlet katkı payı dahil olmak üzere yönetilen fon tutarının 50 milyar TL'nı aştığı bir sistem ile ilgili olarak, gider yapısının tam olarak açıklanması, gider kalemlerinin kapsamlı olarak ele alınması, tüm gider kalemlerinin sektörel bazda ortaya konulması ve bu giderler indirildikten sonraki net getirilerin hesaplanması, hem bu konuda yapılacak olan akademik çalışmalara kaynak oluşturacak hem de politika belirleyici otoritelerin karar almasına yardımcı olacaktır.

Yapılan çalışmada öncelikle emeklilik sistemi üzerindeki giderler "plan kapsamında yapılan kesintiler" ve "fon varlığını azaltan giderler" olarak iki ayrı gruba ayrılmıştır. Peşin ödenen giriş aidatı, ertelenmiş gider aidatı, yönetim ve ara verme gider kesintileri gibi, katılımlar henüz bireysel emeklilik fonlarına yönlendirilmeden, emeklilik planı dahilinde kesilen giderler "plan kapsamında yapılan kesintiler" grubuna, tamamı fon toplam gider kesintisi (FTGK) başlığı altında incelenebilecek olan, fon işletim gider kesintisi (FiGK), aracılık komisyonları, saklama ücreti gibi katılımlar emeklilik fonlarına yönlendirildikten sonra fon varlığı üzerinden yapılan kesintiler de "fon varlığını azaltan giderler" olarak nitelendirilmiştir.

Çalışmada, Emeklilik Gözetim Merkezi'nin (EGM) verilerine göre, bireysel emeklilik sistemi üzerinden 2014 yılı sonuna kadar kümülatif olarak yapılan tüm kesintilerin toplamının 4,341 Milyon TL'nin üzerinde olduğu, bu tutarın 2014 yılı sonuna kadar devam eden ya da sona erdirilmiş sözleşmelere ait toplam katkı payı tutarı olan 40.029.266.799 TL.'nın (EGM 2015, s.12) \% 10,8'ine karşılık geldiği ve henüz yeni sayılabilecek bir sistemde şimdiye kadar yapılan bu kesinti miktarının uluslararası ölçekte de yüksek olduğu belirtilmiştir. Çalışmada yapılan kesintilerin dağılımı da analiz edilerek, toplam kesintilerin \%56'sının fon varlığını azaltan fon işletim gider kesintilerinden oluştuğu, ancak fon varlığını azaltan FTGK tanımına FiGK'nin yanısıra; "alım satım komisyonu", "saklama ücreti” gibi "fon varlığını azaltan diğer gider" kalemlerin de dahil olduğu, ancak fon varlığını azaltıcı "alım satım komisyonu", "saklama ücreti" gibi diğer kesinti kalemlerine toplu verilerin açıklandığı birçok kaynakta yer verilmediği belirtilerek, "fon varlığını azaltan diğer giderlerin" FTGK içindeki 
payının \%6-\%7 civarında olduğu hesaplanarak, bu giderlerin de maliyet analizlerinde dikkate alınması gerektiği belirtilmiştir.

Çalışmada emeklilik şirketine ayrıca ödenen veya yapılan periyodik katkı paylarından kesilen, dolayısıyla emeklilik yatırım fonunda yatırıma yönlendirilmeyen, emeklilik fonlarına yönlendirilmediği için de fon kesintisi veya fon getirisi analizlerinde yer almayan, herhangi bir yerde katılımcıların karşılaştırma yapabileceği bir şekilde ilan edilmeyen "plan kapsamında yapılan kesintiler"in toplam giderler içerisindeki payının, fon işletim gider kesintisine göre giderek azaldığı, ancak emeklilik şirketi tarafından yatırıma yönlendirilmeden emeklilik planı dahilinde kesilen gider kalemlerinin, toplam içinde en düşük paya sahip olduğu 2014 yılında dahi toplam giderlerin \%36'sını oluşturduğu gösterilmiştir.

Çalışmada, bireysel emeklilik sistemi ile ilgili yapılan kesinti hesaplamalarında genellikle sadece "fon işletim gider kesintisinin" dikkate alınması eleştirilerek, 2008-2014 dönemi için "plan kapsamında yapılan kesintiler" grubunda yer alan, "peşin ödenen gider kesintisi", "ertelenmiş peşin ödenen gider kesintisi", "yönetim gider kesintisi" ve "ara verme yönetim gideri kesintisi" oranları da hesaplanarak fon varlığını azaltan FTGK tutarlarına ilave edilmiş ve sistemin maruz kaldığı toplam maliyetler ortaya çıkartılmıştır. Ayrıca genel olarak katılımcıya yansıtılan bilgilerde yanlış anlaşılan diğer bir husus da fon işletim gider kesintisinin tamamının emeklilik yatırım fonlarını yöneten portföy yönetim şirketlerine ödendiği şeklinde bilgidir; halbuki uygulamada sürekli bilgilendirme formu verilerine göre portföy yönetim şirketleri tarafından genellikle 5 ila 50 baz puanı $(\% 0,05$ ila $\% 0,50)$ oranında portföy yönetim şirketine ödeme yapılmakta, kalan fon işletim gideri kesintileri ise fon kurucusu olan emeklilik şirketlerinde kalmaktadır. Yapılan maliyet hesaplamaları sonucunda inceleme döneminde sektörün toplam gider rakamının yönetilen portföye oranının giderek düştüğü, bu oranın en yüksek olduğu 2008'de \%5,83 iken, 2014 yılı itibariyle \%2,34'e düştüğü gösterilmiştir.

Çalışmada 2008-2014 yılları arasındaki tüm gider kalemlerini irdeleyen analiz ortaya konulduktan sonra tüm gider kalemleri dikkate alınarak reel getiri hesaplamaları yapılmış; sadece "fon işletim gider kesintileri" dikkate alınarak yapılan hesaplamalar sonucunda ortalama reel getiri \% 2.01 olarak hesaplanırken, diğer giderlerin de göz önüne alınması durumunda ortalama reel getirinin \% 0,19’a düştüğü gösterilmiştir. Yapılan tüm kesintiler sonucunda sağlanan \% 0,19 reel getiri karşılığında ise, inceleme dönemi içerisinde en düşük toplam kesintinin gerçekleştiği 2014 yılında dahi \%2,34 oranındaki kesinti yapıldığı belirtilerek, yapılan yüksek kesintilerin karşısında ortalama getiri düzeyinin sadece \% 0,19 oranında gerçekleşmesi eleştirilerek kamu desteği olmadan mevcut sistemin gider-getiri yapısının sürdürülemez olduğu sonucuna varılmıştır.

Yapılan çalışma ile; katılımcıların gider ve getiri hesaplarını daha doğru yaparak elde edecekleri faydayı arttırmalarına yardımcı olunması ve politika belirleyicilere daha düşük maliyetli sistem dizaynında katkıda bulunulması hedeflenmektedir. Ayrıca çalışmada ulaşılan sonuçlar dikkate alınarak, karmaşık gider yapısının katılımcılar tarafından kolaylıkla anlaşılabilmesine ve bu giderlerin emeklilik planı bitiminde elde edilecek getiriler üzerindeki etkilerinin değerlendirilmesine yönelik yöntemlerin araştırılması ve Türk emeklilik yatırım fonlarının maliyet yapısını etkileyen faktörlerin incelenmesi bu çalışma ile hedeflenen amaçların geliştirilmesine katkıda bulunacaktır.

Bu kapsamda, çalışmamız beş bölümden oluşmaktadır. İkinci bölümde literatür taraması yapılmaktadır. Üçüncü bölümde sistemde yapılan kesintiler ile ilgili bilgi verilmekte, dördüncü bölümde kullanılan verilerin ne şekilde temin edildiği ve hesaplandığı açıklandıktan sonra veri analizi yapılmakta, son bölümde ise gider ve gelir yapısı ile ilgili değerlendirmeler yapıldıktan sonra çalışmanın sonuçları kısaca değerlendirilmektedir.

\section{LITERATÜR TARAMASI}

Emeklilik fonlarının yönetim ücretleri ile ilgili yapılan çalışmalarda, çoğunlukla kesintilerin fazlalığı eleştirilirken, özellikle Türkiye'de olduğu gibi gönüllülük esasına dayanan ve sistemin henüz yeteri kadar yaygınlaşmadığı ülkelerde sistemin yaygınlaştırılabilmesi ve yeterli kalitenin oluşturulabilmesi için, ücretlerin belirli bir seviyenin altına düşmemesi gerektiğini savunan bazı çalışmalara da rastlanmaktadır. Örneğin Hoexter her gereksiz yönetim giderinin katılımcıların birikimlerini azalttığını savunurken (Hoexter 1970, 134, kaynak; Mitchell, 1998, s. 403), Myers ücretlerin iyice düşmesi sonucunda verilen özel emeklilik hizmetinin kalitesinin de düşeceği, halbuki bazı plan katılımcılarının daha kaliteli hizmet karşılı̆̆ında daha yüksek ücret ödemeye razı olabileceklerinden bahsetmiştir. (Myers 1992, 16, kaynak; Mitchell, 1998 s. 403). Optimal bir emeklilik 
sisteminin özellikleri ve kesinti oranlarına ilişkin çalışmalar devam etse de, sistemlerin en önemli özelliğinin, düşük kesinti oranı olması gerektiği bir çok politika belirleyici tarafından kabul edilmiştir.

BES üzerinden yapılan kesintiler, katılımcıların emeklilik döneminde elde edeceği getiri tutarını önemli ölçüde etkilemektedir. Özellikle bir kerelik alınan ücretlerden ziyade, birikim tutarı üzerinden yapılan "fon toplam gideri kesintisi", "fon işletim gideri kesintisi", "fon yönetim ücreti", "portföy yönetim ücreti" gibi çeşitli isimler altında sürekli olarak yapılan kesintiler emeklilik birikimlerini önemli ölçüde azaltmaktadır. Örneğini İngiltere sistemine yönelik olarak Watson (2010) tarafından yapılan bir çalışmada, Ingiltere'de yıllık ortalama \%1,5 civarında kesinti yapıldı̆̆ı, 40 yıllık bir birikim dönemi sonunda, birikmiş fon tutarı üzerinden yapılan yıllık \%1,5 oranındaki kesintinin, hiç kesinti yapılmaması durumuna göre, emeklilik birikimini \%38 oranında azalttığı, kesinti oranları daha düşük olan Hollanda ile karşılaşıırıa yapııdığı zaman, Hollanda'da, bir çalışanın kendisi ile aynı süre çalışan ve aynı miktarda yıllık katııımda bulunan bir İngiliz çalışana göre \%50 daha fazla emeklilik birikimi elde ettiği sonucuna varılmıştır.

Katılımcıların eline geçecek emeklilik gelirlerini azaltması nedeniyle, Hernandez ve Stewart (2008) tarafından kesinti konusunun otoriteler tarafından da dikkate alındığı ve çalışma konusu yapıldığı belirtilmektedir. Akademisyenlerin ve düzenleyici otoritelerin emeklilik fonlarından yapılan kesintiler üzerine daha fazla yoğunlaşmalarının bir sebebi de, son yıllarda belirlenmiş getiri (DB-defined benefit) planlardaki sorunlar ve fon açıkları nedeniyle, bu tür planların ağırlı̆ının zamanla azalması ve belirlenmiş katılım (DC-defined contribution) planların payının artmasıdır. Zira DB planlarda katılımcılar belirlenmiş getiri tutarlarına dikkat etmekte, emeklilik şirketleri de taahhüt ettikleri getiriyi sağlayabilmek için giderleri bizzat kendileri kısmak istemekteydi. Ancak (DC) planlarda emeklilik şirketinin getiri konusunda herhangi bir taahhüdü bulunmadığından, katılımcı kendi emeklilik getirilerini arttırabilmek için bizzat kendisi gider tutarlarına dikkat etmek durumunda kalmıştır (IOPS, 2014). Ancak bu durum ile birlikte, riskler artan bir şekilde belirlenmiş getiri taahhüdünde bulunan kamudan veya emeklilik şirketlerinden, finansal durumu ve finansal okuryazarlı̆ı yeterli olmayan sıradan bireylere transfer edilmiştir. Zira, asgari getiri garantisi bulunmayan DC planlarda yatırım riski tamamen katıımcının üzerinde olup, doğru yatııım tercihleri yapılabilmesi için emekliliğe yönelik yatııım fırsatlarına ve giderlerine ilişkin bilgilerinin yeterli düzeyde olması, risk tercihlerinin ve beklentilerinin yatırım aşamasında iyi analiz edilip plan kurucusu tarafından yatııım tavsiyesi sağlanması gerekmektedir (Yazıcı, 2014).

Literatürde, Türk bireysel emeklilik sistemi üzerinde var olan tüm ücretleri ve etkilerini konu alan bir çalışmaya rastlanmamakla birlikte, farklı kurumların yayınlarında veya internet sitelerinde ücret ve getiri bilgilerine yer verdikleri görülmektedir. Örneğin, Takasbank Fon Bilgilendirme Platformu'nun (TEFAS), Emeklilik Gözetim Merkezi'nin, Sermaye Piyasası Kurulu'nun ve Kamuyu Aydınlatma Platformu'nun KAP) ${ }^{1}$ internet sitelerinde fon yönetim ücretlerine ilişkin toplu olarak bilgilere yer verilmekte ayrıca Emeklilik Gözetim Merkezi tarafından hazırlanan yıllık Bireysel Emeklilik Gelişim Raporlarında da, BES üzerinden yapılan kesintiler ile ilgili karşılaştırmalı verilere yer verilmektedir. Ayrıca bireysel emeklilik şirketlerinin kendi internet siteleri üzerinden de BES planları ve kesinti oranları ile ilgili daha detaylı bilgilere yer verilmekte, ancak verilen bu bilgiler sadece o şirkete ait planlar ile ilgili olduğu için katılımının bu bilgileri kullanarak karşılaştırma yapma imkanı bulunmamaktadır.

\section{SISTEMDE YAPILAN KESINTILER}

Emeklilik şirketleri, plan katııımcılarına sunduğu hizmetler karşılı̆̆ında bazı kesintiler yapmaktadır. Bireysel emeklilik sistemi üzerinden 2014 yılı sonuna kadar kümülatif olarak yapılan FiGK, peşin ödenen ve ertelenen giriş aidatları, yönetim ve ara verme gider kesintileri toplamı 4.176 Milyon TL olup (EGM, 2014), TFGK ve FiGK arasındaki fark da ilave edildiği zaman yapılan tüm kesintilerin toplamı 4,341 Milyon TL'nın üzerindedir. Öte yandan şunu da belirtmek gerekir ki, yapılan analizde her yıl kesilen nominal tutarlar dikkate alınmış olup, yapılan kesintilerin bugünkü değerinin bulunması yoluna gidilmemiştir. Söz konusu analizin yapılması durumunda yapılan kesintilerin bugünkü değeri daha yüksek olacaktır. Zira söz konusu kesintiler yapılmasaydı bu tutarlar sistemde kalacak ve meydana gelecek fon toplam değeri artışına bağlı olarak değerlerini artıracaktı. Bireysel emeklilik sistemi üzerinden 2014 yılı sonuna kadar kümülatif olarak yapılan tüm kesintilerin toplamı 4,341 Milyon TL. olarak gerçekleşmiş olup, bu tutar 2014 yılı sonuna kadar devam eden ya da sona erdirilmiş

\footnotetext{
${ }^{1} \mathrm{http} / / /$ www.kap.gov.tr/yatirim-fonlari/yatirim-fonlari-bilgi-formu.aspx?madde_no=1043\&durum_=1\&eyf_=1
} 
sözleşmelere ait toplam katkı payı tutarı toplamı olan 40.029.266.799'TL.'nın (EGM 2015, s.12) \% 10,8'ine karşılık gelmektedir. Sadece 2014 yılında yapılan kesintilerin toplam tutarı ise 850 Milyon TL'dir.

Ülkelerin BES uygulamalarına göre yapılan kesinti tutarları da değişmektedir. OECD tarafından yapılan çalışmada, 2011 yılında Türkiye, karşılaştırılan diğer OECD ülkelerine göre kesintilerin en yüksek olduğu grupta yer almaktadır (OECD, 2013). Yazıcı (2014) tarafından bu yüksekliğin esas olarak sistemin tamamen gönüllü katııma dayalı olmasından ve toplam fon büyüklüğünün küçük olmasından kaynaklandığı değerlendirilmiştir.

Bireysel emeklilik sistemi üzerindeki giderler mevzuat ile FTGK, peşin ödenen giriş aidatı, yönetim ve ara verme gider kesintileri toplamı olarak belirtilmekte, ilave olarak da FiGK, fon yönetim ücreti ve ertelenmiş gider aidatı, aracılık komisyonları gibi farkı gider tanımlamaları da bulunmaktadır. Bu giderlerden peşin ödenen giriş aidatı, yönetim ve ara verme gider kesintileri ve ertelenmiş gider aidatları yatııımlar henüz bireysel emeklilik fonlarına yönlendirilmeden emeklilik planı dahilinde kesilmekte; tamamı FTGK başlı̆̆ altında incelenebilecek olan, FiGK, aracııık komisyonları, saklama ücreti gibi bazı giderler de katılımlar emeklilik fonlarına yönlendirildikten sonra fon varlığı üzerinden kesilmektedir. Bu nedenle birinci grup giderleri "plan kapsamında yapılan kesintiler", ikinci grup giderleri de "fon varlığını azaltan giderler" olarak nitelendirmek mümkündür.

Bireysel Emeklilik Sistemi Hakkında Yönetmelikte yapılabilecek kesinti türleri, giriş aidatı, yönetim gider kesintisi (YGK) ve FTGK olarak belirlenmiş olup, bu kesinti tiplerine ilişkin bilgiler kısaca aşağıda yer almaktadır;

\subsection{Giriş Aidatı}

Sisteme ilk giriş aşamasında peşin olarak verilmekte veya ertelenmiş olarak tahsil edilmektedir. Giriş aidatı, esas olarak başlangıçta müşteriyi kazanma amacıyla yapılan maliyet, satış, pazarlama ve dağııım gideri olarak düşünülse de, pratik uygulamada bu amacı karşılamaktan daha çok, sistemden erken ayrılma ya da planın başka bir şirkete aktarımı durumunda caydırıcı ceza işlevi görmektedir. Emeklilik Gözetim Merkezi tarafından hazırlanan gelişim raporlarında giriş aidatı; peşin ödenen giriş aidatı ve ertelenen giriş aidatı olarak 2 ayrı kaleme ayrılarak incelenmektedir. 2014 yılı Gelişim Raporunda yer aldığı üzere, BES üzerinden 2014 yılı sonuna kadar kümülatif olarak toplam 876,960,000 TL giriş aidatı kesintisi gerçekleştirilmiş, bu tutarın 375.840 .000 TL'sı peşin olarak, 501.120.000 TL'sı ise ertelenmiş olarak tahsil edilmiştir. Sistemin başlangııından itibaren, 2014 yılı sonuna kadar tahsil edilen kesintiler içerisinde giriş aidatları \%21 oranında bir paya sahip bulunmaktadır. Toplam kümülatif kesintiler içinde ertelenen payların \%13, peşin alınan giriş aidatlarının ise \% 8'lik bir paya sahip olması, giriş aidatlarının esas olarak sisteme girişte şirketin karşılaştığı maliyetleri karşılamaktan çok, ayrılmaları caydırıcı bir işlev için kullanıldığını göstermektedir.

2013 yılından önceki uygulamada giriş aidatı tutarı, aylık brüt asgari ücret (ABAÜ) tutarının yarısı ile sınırlandırımışken, 2013 yılından sonraki uygulamada giriş aidatı tutarı sistemden erken ayrılmaları caydırmak amacıyla, ABAÜ tutarının \%75'ine yükseltilmiş (peşin olarak tahsil edilecek olan tutar ABAÜ tutarının \%10'u ile sınırlandırımıştır), ayrıca katııımının sistemde kalma süresi uzadıkça, ertelenmiş giriş aidatı tutarını azaltan kademeli bir sistem dizayn edilmiştir. Hatta mevzuat uyarınca, katılımcı sistemde 10 yıl kaldıktan sonra hiç ertelenmiş giriş aidatı alınmaması gerekmektedir. (Yazıcı, 2014)

\subsection{Yönetim Gideri Kesintisi (YGK)}

YGK, yatırılan katkı payları üzerinden, katkı payları ödendikçe bir kereliğine yapılan bir kesintidir. 2013 yııı öncesi dönemde azami YGK oranı \%8 iken, 2013 yılından itibaren \%2'ye düşürülmüştür. Uygulamada yönetim gider kesintisi tutarları plan bazında değişmekte, ayrıca aynı plana dahil olan katılımcıların periyodik yatırım tutarları arttıkça, uygulanan oranın azalması uygulaması da sıkça görülmektedir. Ayrıca bazı planlarda da, başlangıçta belirli bir tutarın üzerindeki katııım tutarını tek seferde yatıran katııımcılardan, sonrasında yapılacak katkı payı ödemeleri için herhangi bir yönetim gider kesintisi alınmaması uygulamasına da rastlanılmaktadır. BES üzerinden 2014 yılı sonuna kadar kümülatif olarak toplam 918.720.000TL yönetim gideri kesintisi gerçekleştirilmiştir (EGM, 2015).

Ödenen katkı payları üzerinden yapılan kesintilere ilave olarak, katılımcının 3 aydan fazla ödemeye ara vermesi durumunda şirketler ara verilen her ay için en fazla 2 TL ek yönetim gideri kesintisi alabilmekte, ayrıca katııımının ödemeye bir yıldan daha fazla ara vermesi durumunda da, şirket tarafından ödenen sabit giderler, 
katılımcının bireysel emeklilik hesabındaki birikiminden tahsil edilebilmektedir. Bu şekilde yapılan kesintilerin, tüm kesintilere oranı yaklaşık olarak \%1 civarındadır (EGM, 2015).

\subsection{Fon Toplam Gideri Kesintisi (FTGK)}

07.04.2001 tarihli "Bireysel Emeklilik Tasarruf ve Yatırım Sistemi Kanunu” ile fon varlıklarından FiGK yapılabileceği düzenlenmiş, 09.11.2012 tarihli Sistem Yönetmeliği ile de FTGK tanımı getirilmiş ve fona ilişkin giderlerin karşılanması için fondan mevzuatla belirlenen sınırlar dahilinde kesinti yapılabileceği belirtilmiştir. 26.02.2013 tarihli Emeklilik Planı Hakkında Genelge ile de, fondan yapılan FiGK, aracılık komisyonu ve diğer tüm gider ve masrafların toplamının fon net varlık değerine oranının, FTGK oranını aşamayacağı belirlenmiştir. Dolayısı ile FTGK, hem FiGK tutarını içermekte, hem de alım satım komisyonu, ihraç izni giderleri, tescil ve ilan giderleri, sigorta ücretleri, noter harç ve tasdik giderleri, bağımsız denetim ücreti, saklama ücreti, alınan kredi faizi, vergi, resim, harç v.b. gibi fon aktifinden yapılan tüm kesintileri içermektedir. Aşağıda yer alan Tablo:1'de FTGK içinde yer alan FiGK tutar ve oranları ile, fon varlığından kesintisi yapılan diğer giderler yer almaktadır.

Tablo 1: Fon Varlığını Eksilten FTGK, FiGK, Komisyon Harcamaları ve Diğer Harcamalar

\begin{tabular}{|c|c|c|c|c|c|}
\hline Yıl & $\begin{array}{c}\text { Toplam Kesinti } \\
\text { (FTGK) }\end{array}$ & $\begin{array}{c}\text { Yönetim Ücreti } \\
\text { (FiGK) }\end{array}$ & $\begin{array}{c}\text { Komisyon } \\
\text { Harcaması }\end{array}$ & Diğer Harcamalar & FiGK/FTGK (\%) \\
\hline $\mathbf{2 0 0 7}$ & 99.218 .532 & 85.789 .686 & 7.434 .364 & 5.994 .482 & 86,47 \\
\hline $\mathbf{2 0 0 8}$ & 102.029 .636 & 93.946 .726 & 5.426 .644 & 2.656 .266 & 92,08 \\
\hline $\mathbf{2 0 0 9}$ & 189.793 .936 & 175.708 .798 & 10.518 .377 & 3.566 .761 & 92,58 \\
\hline $\mathbf{2 0 1 0}$ & 255.576 .891 & 239.483 .885 & 12.721 .931 & 3.371 .074 & 93,70 \\
\hline $\mathbf{2 0 1 1}$ & 308.138 .048 & 291.517 .294 & 12.609 .493 & 4.011 .261 & 94,61 \\
\hline $\mathbf{2 0 1 2}$ & 402.531 .203 & 378.639 .458 & 19.128 .244 & 4.763 .501 & 94,06 \\
\hline $\mathbf{2 0 1 3}$ & 446.175 .217 & 415.546 .647 & 17.359 .717 & 13.268 .853 & 93,14 \\
\hline $\mathbf{2 0 1 4}$ & 557.175 .719 & 522.831 .911 & 20.397 .677 & 13.946 .131 & 93,84 \\
\hline
\end{tabular}

Kaynak: Tablo SPK ve Takasbank internet sitesinde ve yer alan emeklilik yatırım fonu gider verileri kullanılarak yazar tarafından hazırlanmıştır.

2013 öncesi uygulamada, FiGK oranı tavanı için fonlar arasında herhangi bir ayrım yapılmamış, limit tutarı günlük azami yüzbinde 10 (yıllık \%3,65) olarak düzenlenmişken, 2013 tarihinden itibaren ise FTGK tutarları esas alınmış, fon varlığından alınabilecek diğer tüm kesintiler fon grupları bazında ayrıştııımış ve 2013 öncesi belirlenen azami tutar daha da aşağıya çekilmiştir. 2013 yılı sonrasında FTGK oranları; "para piyasası fonları"” için günlük azami yüzbinde 3 (yıllık \%1,09), "kamu ve özel sektör borçlanma araçları, kıymetli madenler, endeks fonları ve benzeri fonlar" için günlük azami yüzbinde 5,25 (yıllık \%1,91), "hisse senedi ve benzeri aktif yönetilen fonlar ${ }^{4 \prime \prime}$ için ise günlük azami yüzbinde 6,25 (yıllık $\% 2,28$ ) olarak uygulanmaktadır.

Bunlara ilave olarak, Devlet katkısı ile oluşturulan fonlardan da yıllık azami \% 0,365 oranında FTGK kesilmektedir.

Aşağıda yer alan Tablo 2'de 2013 yılı öncesi mevzuat çerçevesinde geçerli olan üst sınırlar ile fiili olarak uygulanan YGK ve FTGK oranları ve 2013 yılı sonrasında geçerli oranları gösteren bilgiler yer almaktadır.

\footnotetext{
2. Grup; Kamu, özel sektör ve karma likit fonlar.

3 II. Grup; Borçlanma araçları, kıymetli madenler, endeks, kamu borçlanma araçları, özel sektör borçlanma araçları, karma borçlanma araçları, uluslararası borçlanma araçları, kıymetli madenler, altın ve dengeli fonlar.

${ }^{4}$ III. Grup; Hisse senedi, uluslararası hisse senedi, küçük şirketler hisse senedi, yabancı ülke, sektör, esnek, karma, uluslararası karma ve fon sepeti fonları.
} 
Tablo 2: BES Kesintilerinde 2013 Yılı Sonrası Sağlanan Düşüş

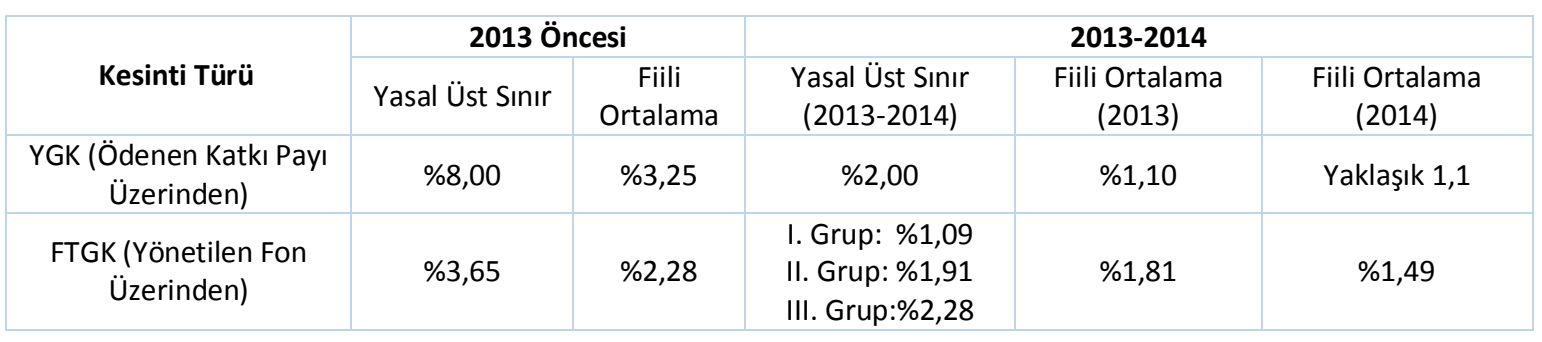

Kaynak: EGM 2015

Ancak burada mevzuat ile belirlenen "fon toplam gider kesintisi" ifadesinden, her türlü kesintinin dahil olduğu üst limit anlamını çıkartmamak gerekmektedir. Zira, yukarıda bahsedilen giriş aidatı ile yönetim gider kesintileri "fon toplam gider kesintisi" tutarına dahil değildir. Fon toplam gider kesintisinin çok büyük bir kısmını oluşturan ${ }^{5}$ fon işletim gider kesintisi aktif büyüklüğün belirli bir oranı olarak hesaplanmakta, günlük olarak kesilmekte ve fon toplam değerini her gün eksiltmektedir. Yönetim gideri kesintisi ise katkı payları üzerinden bir defalığına tahsil edilmekte, kalan tutar yatıııma yönlendirilmektedir. Ancak yatırıma yönlendirilen baz tutarı azalttığı için de önemli bir etkiye sahiptir. Giriş aidatı ise sözleşme imzalanırken peşin olarak (peşin alınacak aidat tutarı uygulamada aylık taksitler halinde tahsil edilmektedir) veya ertelenen giriş aidatı olarak tahsil edilmektedir. BES üzerinden 2014 sonuna kadar kümülatif olarak toplam 2.338.560.000 TL fon işletim gider kesintisi gerçekleştirilmiş olup bu tutar, yapılan tüm kesinti tutarlarının \%56'sını oluşturmaktadır. (EGM 2015)

FTGK, günlük belirlenen gider oranlarının, fon toplam değeri ile çarpılması sonucu hesaplandığından, katılımıının sistemde kalma süresine bağıı olarak artmaktadır. Örneğin 20 yıl devam eden bir emeklilik planında, 20 yı önce yapılan ve yatıııma yönlendirilen katkı payı üzerinden, 20 yıl boyunca her gün kesinti yapılmaktadır. Bu yüzden de diğer maliyetlerin yanında FTGK'ye daha fazla önem verilmeli ve kesinti sonuçlarının neler olduğu hakkında plan katıımcıları daha fazla bilgilendirilmelidir.

\section{VERI TEMINI VE ANALIZi}

\subsection{Veri Temini}

Yukarıda da detaylı olarak izah edildiği üzere emeklilik şirketleri tarafından 3 şekilde ücret tahsilatı yapılmaktadır. illk olarak plan katılımcısı bir plana katıldığı zaman, asgari ücretin belirli bir oranı tutarında giriş aidatı ödemekte, daha sonra periyodik olarak katılımda bulunmakta ve YGK katılım miktarından kesildikten sonra, kalan katııım tutarı yatıııma yönlendirilmektedir. Buraya kadar, yani katılımlar yatıııma yönlendirilmeden önce yapılan kesintiler fon varlığı üzerinden değil, katılımcının dahil olduğu plana göre belirlenen kesintilerdir. Bu 2 kesinti yapıldıktan sonra ise kesinti yapılmış katkı payları katıımcının tercihine göre emeklilik fonlarına yönlendirilmekte, bu aşamadan sonra fon aktif değeri üzerinden her gün kesinti yapılarak, emeklilik yatırım fonunun aktif büyüklüğü azaltılmaktadır. Fon aktif değeri üzerinden yapılan bu kesinti ise plana dahil edilen fonlara göre yani fon bazlı olarak belirlenmektedir. Dolayısıyla yapılan kesintilerle ilgili bütüncül bir çalışma yapabilmek için, hem plan bazında alınan giriş aidatı ve YGK, hem de fon bazında tahsil edilen FTGK (FiGK ve fon büyüklüğü üzerinden alınan diğer giderler) verilerine ihtiyaç bulunmaktadır.

Türkiye'de BES ile ilgili kesintiler fon bazında veya emeklilik planı bazında emeklilik şirketlerinin internet sayfalarında, fon izahnamesindeki bilgilerin özet olarak yer aldığı tanıtım formunda, fon içtüzüğünde, fonların yıllık raporlarında, tanıtım kılavuzlarında yer almaktadır.

Ancak bu veriler fon veya emeklilik planı bazında olup karşılaştırma yapma imkanı vermekten uzaktır.

Diğer yandan Türkiye'de toplam kesinti oranlarının birlikte yer aldığı kaynaklar da bulunmaktadır. Örneğin KAP üzerinde, "fon iç tüzüğünde yer alan fon işletim gideri", "uygulanan fon işletim gideri" ve "fon toplam gider

\footnotetext{
${ }^{5}$ SPK internet sitesinde yer alan ayrıntılı fon gider rakamlarının toplanması sonucunda, 2014 yılında fon toplam gider kesintisinin \% 93,8'ini, 2013 yılında da \%93,1'ini fon işletim gider kesintisinin oluşturduğu görülmüştür.
} 
kesintisi" verilerine yer verilmektedir. EGM ve TEFAS'da ise "fon bazında fon işletim gideri kesintisi" oranları tüm fonlara ilişkin olarak verilmektedir.

SPK'nın internet sitesinde ise, diğer toplu veri sağlayan sitelere benzer olarak, giriş aidatı ve YGK rakamlarına yer verilmemekle birlikte, diğer sitelerde yer alan FTGK veya FiGK değerlerinin ayrıntılarına inilmekte, fonların günlük yönetim ücreti oranı ile dönem içerisinde yapılan harcamaların toplamı, dönem içerisinde yapılan harcamaların ortalama fon toplam değerine oranı gibi ilave bilgilere de yer verilmektedir. SPK'nın internet sitesinde ayrıca alım satım komisyonu oran ve tutarları (hisse senedi, tahvil ve bono, ters repo, Borsa Para Piyasası, yabancı menkul kıymet komisyon oran ve tutarları) ile ihraç izni giderleri, tescil ve ilan giderleri, sigorta ücretleri, noter harç ve tasdik giderleri, bağımsız denetim ücreti, katılma belgesi basım giderleri, saklama ücreti, alınan kredi faizi, vergi, resim, harç vb. gibi giderlere de her bir fon detayında ve yıllık bazda yer verilmektedir.

Görüldüğü üzere yukarıda yer alan toplu verilerin yer aldığı kaynaklarda fon bazında tamamen FTGK veya FiGK ile ilgili bilgilere yer verilmekte, katılımcının ödediği giriş aidatı ve YGK ile ilgili, toplu ve karşılaştırmaya imkan veren bir veri seti bulunmamaktadır. Plan bazında toplu verilere ise EGM'nin internet sayfasından erişilebilmekte, örneğin 2014 yılı için 973 adet emeklilik planı ile ilgili FiGK rakamları ile ilgili bilgiye ulaşılabilmekte, ancak giriş aidatı ve YGK bilgileri bu sayfada da yer almamaktadır.

Diğer yandan 2004 yılından itibaren EGM tarafından yıllık olarak yayınlanmakta olan bireysel emeklilik sistemi yıllık gelişim raporlarında (BESYGR), yönetim gider kesintileri tüm sektörün toplamı olarak aylık bazda verilmekte, yıllar itibari ile de kümülatif olarak gösterilmektedir. Aynı raporlarda ayrıca sistemde katılımcılardan yapılan toplam kesintilere yıllık bazda yer verilmekte, ayrıca yapılan toplam kesintiler içerisinde ara verme yönetim gideri kesintisi, ertelenen giriş aidatı, peşin ödenen giriş aidatı, fon işletim gider kesintisi ve yönetim gider kesintisinin yüzdesel olarak payları da grafik olarak verilmektedir. Ancak bu veriler de yıllık olarak verilmemekte, 2008 yılından itibaren birikimli olarak verilmektedir. Örneğin, 2014 yılı raporunda açıklanan fon işletim gider kesintisinin toplam gider rakamı içerisinde payının \% 56 olmasına ilişkin bilgi, sadece 2014 yılına ait olan bir bilgi değil, 2007-2014 yılı arasındaki döneme ait toplam birikimli rakamlar ile oluşturulmuş bir bilgidir.

Aşağıda yer alan Tablo 3'de 2007-2014 yıllları arasındaki yıllık BESYG raporlarından üretilen birikimli gider dağılım yüzdelerini gösteren tablo yer almaktadır (Ancak BESYG raporlarında FTGK rakamlarından değil de FiGK rakamlarından bahsedildiği için, Tablo 3 FiGK dışında FTGK rakamına dahil olan kesintileri içermemektedir):

Tablo 3: Birikimli Gider Dağılım Yüzdeleri (2007-2014)

\begin{tabular}{|c|c|c|c|c|c|}
\hline Yıllar & $\begin{array}{c}\text { Fon İşletim } \\
\text { Gideri (\%) }\end{array}$ & $\begin{array}{c}\text { Yönetim Gider } \\
\text { Kesintisi (\%) }\end{array}$ & $\begin{array}{c}\text { Peşin Ödenen } \\
\text { Gider Aidatı (\%) }\end{array}$ & $\begin{array}{c}\text { Ertelenen Gider } \\
\text { Aidatı (\%) }\end{array}$ & $\begin{array}{c}\text { Ara Verme Yönetim } \\
\text { Gider Kesintisi (\%) }\end{array}$ \\
\hline $\mathbf{2 0 0 7}$ & 35 & 38 & 16 & 10 & 1 \\
\hline $\mathbf{2 0 0 8}$ & 38 & 35 & 14 & 12 & 1 \\
\hline $\mathbf{2 0 0 9}$ & 41 & 32 & 12 & 14 & 1 \\
\hline $\mathbf{2 0 1 0}$ & 45 & 30 & 11 & 13 & 1 \\
\hline $\mathbf{2 0 1 1}$ & 49 & 28 & 9 & 13 & 0 \\
\hline $\mathbf{2 0 1 2}$ & 52 & 27 & 8 & 12 & 1 \\
\hline $\mathbf{2 0 1 3}$ & 54 & 24 & 9 & 12 & 1 \\
\hline $\mathbf{2 0 1 4}$ & 56 & 22 & 9 & & 1 \\
\hline
\end{tabular}

2014 yılına kadar olan toplam FiGK tutarları, toplam kesintilerin sadece \%56'sını oluşturduğundan dolayı, BES katılımcısının maruz kaldığı tüm giderler ile ilgili bütüncül değerlendirmelerde bulunabilmek için, BESYR'lerde yer alan kümülatif toplam gider rakamlarından ve gider kalemlerinin kümülatif dağılım yüzdelerinden faydalanılarak, geçmişe dönük olarak yıl bazında tüm gider türleri yaklaşık olarak hesaplanmıştır.

Örneğin, 2014 yılı sonu itibariyle toplam kümülatif gider rakamı olan 4.176 Milyon TL kesinti tutarından (EGM,2015), 2013 yılı kümülatif kesinti toplamı olan 3.326 milyon TL (EGM, 2014) çıkartılarak, 2014 yılına ilişkin toplam kesinti tutarının 850 milyon TL. olduğu bulunmuş, sonrasında da yukarıda yer alan Tablo 3'de yer alan birikimli yüzdelerden yıllara göre gider dağılım tutarları ve yüzdeleri hesaplanmıştır. Örneğin 2014 yılına ilişkin birikimli toplam gider rakamı olan 4.176.000.000 TL rakamı ile aynı yılın birikimli fon işletim yüzdesi olan \%56 oranının çarpımından, aynı hesaplamanın 2013 yılı için yapılması sonucu bulunan tutar çıkartılarak, 2014 yılına 
ait yıllık fon işletim giderleri yaklaşık ${ }^{6}$ olarak bulunmuştur. Ayrıca bu şekilde bulunan fon işletim gider kesintisi rakamları da SPK internet sitesinde yer alan ve tek tek fon bazında verilen rakamların toplanması ile bulunan, yıllık fon yönetim gideri rakamları ile karşılaştırılarak, birikimli yüzdelerin baz alınması ile bulunan tutarların doğruluğu test edilmiştir.

Yapılan karşılaştırma sonucu her 2 farklı kaynaktan elde edilen fon işletim ve fon yönetim ücretlerinin birbirlerine oldukça yakın olduğunun görülmesi üzerine, bu yöntem ile üretilen veriler üzerinden çalışmaya devam edilmiştir. Örneğin yukarıda yer alan birikimli rakamlar ve birikimli yüzdeler kullanılarak 2013 yılı için fon işletim gideri 414.400.000 TL., 2014 yılı için de 542.520.000 TL olarak hesaplanmış, SPK sitesinde tek tek fon bazında yer alan emeklilik fonlarının fon işletim giderlerinin toplanması sonucu bulunan tutarlar ise 2013 yılı için 415.546.647 TL. ve 522.831.911 TL olarak hesaplanmıştır ${ }^{7}$.

Aşağıda yer alan Tablo 4'de, bu yöntem kullanılarak üretilmiş olan toplam gider ve fon işletim gideri bilgileri, Tablo 5'de ise gider çeşitlerinin yıllık olarak yüzdesel dağılımı yer almaktadır.

Tablo 4: Toplam Gider ve Fon İşletim Gideri Tablosu

\begin{tabular}{|c|c|c|c|c|c|}
\hline Yıllar & $\begin{array}{c}\text { Birikimli Toplam } \\
\text { Gider }\end{array}$ & $\begin{array}{c}\text { Birikimli Fon Işletim } \\
\text { Gideri }\end{array}$ & $\begin{array}{c}\text { Yılık Toplam } \\
\text { Gider }\end{array}$ & $\begin{array}{c}\text { Yılık Fon İşletim } \\
\text { Gideri }\end{array}$ & $\begin{array}{c}\text { Fon Işletim } \\
\text { Gideri }\end{array}$ \\
\hline $\mathbf{2 0 0 7}$ & 436.813 .356 & $152.884 .674,60$ & - & - & - \\
\hline $\mathbf{2 0 0 8}$ & 725.501 .434 & $275.690 .544,92$ & 288.688 .078 & 122.805 .870 & $43 \%$ \\
\hline $\mathbf{2 0 0 9}$ & 1.082 .518 .489 & $443.832 .580,49$ & 357.017 .055 & 168.142 .036 & $47 \%$ \\
\hline $\mathbf{2 0 1 0}$ & 1.510 .653 .721 & $679.794 .174,45$ & 428.135 .232 & 235.961 .594 & $55 \%$ \\
\hline $\mathbf{2 0 1 1}$ & 2.027 .000 .000 & $993.230 .000,00$ & 516.346 .279 & 313.435 .826 & $61 \%$ \\
\hline $\mathbf{2 0 1 2}$ & 2.657 .000 .000 & $1.381 .640 .000,00$ & 630.000 .000 & 388.410 .000 & $62 \%$ \\
\hline $\mathbf{2 0 1 3}$ & 3.326 .000 .000 & $1.796 .040 .000,00$ & 669.000 .000 & 414.400 .000 & $62 \%$ \\
\hline $\mathbf{2 0 1 4}$ & 4.176 .000 .000 & $2.338 .560 .000,00$ & 850.000 .000 & 542.520 .000 & $64 \%$ \\
\hline
\end{tabular}

Kaynak: EGM 2007, EGM 2008, EGM 2009, EGM 2010, EGM 2011, EGM 2012, EGM 2013, EGM 2014 , EGM 2015 verileri ile SPK verileri esas alınarak, yazar tarafından yapılan hesaplamalar sonucu hazırlanmıştır.

Tablo 5: BES Katılımcıları Üzerindeki Gider Yükünün Yılık Yüzdesel Dağılımı

\begin{tabular}{|c|c|c|c|c|c|}
\hline Yıllar & $\begin{array}{c}\text { Fon Işletim } \\
\text { Gideri }\end{array}$ & $\begin{array}{c}\text { Yönetim Gider } \\
\text { Kesintisi }\end{array}$ & $\begin{array}{c}\text { Peşin Ödenen Gider } \\
\text { Aidatı }\end{array}$ & $\begin{array}{c}\text { Ertelenen Gider } \\
\text { Aidatı Verme } \\
\text { Yönetim Gider } \\
\text { Kesintisi }\end{array}$ \\
\hline $\mathbf{2 0 0 8}$ & $43 \%$ & $30 \%$ & $11 \%$ & $15 \%$ \\
\hline $\mathbf{2 0 0 9}$ & $47 \%$ & $26 \%$ & $8 \%$ & $1 \%$ & $1 \%$ \\
\hline $\mathbf{2 0 1 0}$ & $55 \%$ & $25 \%$ & $8 \%$ & $1 \%$ & $1 \%$ \\
\hline $\mathbf{2 0 1 1}$ & $61 \%$ & $22 \%$ & $3 \%$ & $13 \%$ & $1 \%$ \\
\hline $\mathbf{2 0 1 2}$ & $62 \%$ & $24 \%$ & $5 \%$ & $1 \%$ & $9 \%$ \\
\hline $\mathbf{2 0 1 3}$ & $62 \%$ & $13 \%$ & $13 \%$ & $1 \%$ & $1 \%$ \\
\hline $\mathbf{2 0 1 4}$ & $64 \%$ & $14 \%$ & $9 \%$ & $3 \%$ \\
\hline
\end{tabular}

\footnotetext{
6 Sonuçların yaklaşık olarak hesaplanmasının sebebi BESYG raporlarında yer alan yüzde rakamlarının virgülden sonra devam etmemesidir. Konuyla ilgili olarak EGM'den yıllık olarak toplam ve fon bazında veri talebinde bulunulmuş, ancak EGM'den, kamuoyu ile paylaşılan verilerin, yayımlanan haftalık BES göstergeleri, yıllık gelişim raporlarında yer alan veriler ve yıllık gelişim raporlarında yer alan grafiklerin bazılarına ilişkin referans tabloları ile sınırlı olduğuna ilişkin cevap alınmıştır.

EGM kaynaklarından hesaplanan FiGK tutarı ile, SPK sitesinde yer alan portföy yönetim ücreti rakamlarının tutarlı olduğunun görülmesi, işletim gideri dışında SPK sitesinde yer alan ve FTGK rakamına dahil olan, alım satım komisyonu tutarları ile ihraç izni giderleri, tescil ve ilan giderleri, sigorta ücretleri, noter harç ve tasdik giderleri, bağımsız denetim ücreti, katılma belgesi basım giderleri, saklama ücreti, alınan kredi faizi, vergi, resim, harç vb. gibi giderler kalemlerinin yukarıda belirtilen yüzdesel gösterimlerin içine hiç dahil edilmediğini de gösterebilir. FTGK ve FIGK rakamları arasındaki fark 2013 yılı için 30.6 milyon TL., 2014 yılı için 34,3 milyon TL. olarak gerçekleşmiştir. Yüzdesel oranlar kullanılarak yaklaşık değerler elde edildiği için bu konuda kesin bir sonuca ulaşılamamaktadır. Ancak FTGK ile FiGK arasındaki fark EGM tarafından yayınlanan konsolide verilerde Tablo 4'de yer verilen "birikimli toplam gider" rakamı içerisinde dikkate alınmıyor ise bu durum toplam gider tutarının eksik hesaplandığı anlamına gelecek olup, aradaki farkın da dikkate alınmaya başlanması gerekmektedir. Çalışmanın devamında arada kalan farkın ilan edilen birikimli toplam gider rakamı içerisinde yer aldığı kabul edilmiştir.
} 
Kaynak: EGM 2007, EGM 2008, EGM 2009, EGM 2010, EGM 2011, EGM 2012, EGM 2013, EGM 2014, EGM 2015 verileri ile SPK verileri esas alınarak, yazar tarafından yapılan hesaplamalar sonucu hazırlanmıştır.

Veri seti oluşturulurken ayrıca getiri, reel getiri, giderlerden arındırılmış reel getiri ve ortalama reel getiri rakamları da SPK internet sitesinde yer alan veriler ile EGM verileri esas alınarak hesaplanmıştır. Bireysel emeklilik fonlarının yıllık nominal getiri rakamlarını daha önce bahsedilen veri kaynaklarından elde etmek mümkünken, tüm sektörün çalışma konusu olan 2008-2014 yılları arasındaki reel getiriler emeklilik fonlarının yılbaşı ve yıl sonu birim fiyatlarındaki artış dikkate alınarak hesaplanmıştır. Yıl içerisinde kurulmuş ve sene başında mevcut olmayan fonlar bu hesaba dahil edilmemiş, ertesi yılın başından itibaren hesaplamalara dahil edilmiştir. Bu amaçla 2008 yılında 64, 2009 yılında 97, 2010 yılında 120, 2011 yılında 128, 2012 yılında 128, 2013 yılında 145 ve 2014 yılı için de 238 adet fonun getirisi dikkate alınmış, daha sonra her fon bazında elde edilen getiriler, fon bazında "ortalama fon toplam değerleri" ile ağırlıklandırılarak yıllık fon getirileri hesap edilmiştir. Sonrasında elde edilen ve tüm emeklilik fonlarını temsil eden yıllık nominal getiri rakamları ile yıllık enflasyon rakamları (TÜFE) dikkate alınarak reel getiriler hesaplanmıştır. Sonrasında da elde edilen bu getiri rakamları açıklanmış olan bazı rakamlar ile kıyaslanarak yöntemin doğruluğu kontrol edilmiştir. ${ }^{8}$

Ancak bu analiz FTGK içinde sadece FiGK payı dikkate alınarak yapılmıştır. FTGK içinde emeklilik şirketleri tarafından işletim gideri olarak fon varlığından tahsil edilen giderlerin yanısıra, dağılımı Tablo 6'da gösterilen, alım satım komisyonları, ihraç izni giderleri, tescil ve ilan giderleri, sigorta ücretleri, noter harç ve tasdik giderleri, bağımsız denetim ücreti, katılma belgesi basım giderleri, saklama ücreti, alınan kredi faizi, vergi, resim, harç vs. gibi, fon varlığını azaltan diğer kesintiler de mevcuttur. Bu tutarlar emeklilik şirketinin geliri olmamakta ancak fonun idaresi için aracı kurum, merkezi saklamacı, bağımsız denetim firmaları gibi kuruluşlara verilmektedir. Yıllık BEGS raporlarında yer alan kümülatif yüzdesel dağılım analizlerinde sadece FiGK oranları belirtilse de, fon varlığını azaltan bu diğer kalemlerin de toplam maliyet rakamına dahil edilmesi gerekmektedir. Aşağıda yer alan Tablo 6'da SPK internet sitesinde yıllık olarak fon bazında yer alan FTGK kalemlerinden üretilmiş olan FIGK, komisyon harcamaları, diğer harcama rakamları ve FiGK tutarına dahil olmayan ama FTGK içinde yer alan kesinti rakamları yer almaktadır.

Tablo 6: FTGK, FiGK, Komisyon Harcamaları, Diğer Harcamalar, FTGK ve FiGK Farkları

\begin{tabular}{|c|c|c|c|c|c|}
\hline Yıllar & FTGK & FiGK & Komisyon Harcaması & $\begin{array}{c}\text { Diğer } \\
\text { Harcamalar }\end{array}$ \\
\hline $\mathbf{2 0 0 6}$ & 53.119 .083 & 45.265 .308 & 4.305 .168 & 3.548 .607 & 7.853 .775 \\
\hline $\mathbf{2 0 0 7}$ & 99.218 .532 & 85.789 .686 & 7.434 .364 & 5.994 .482 & 13.428 .846 \\
\hline $\mathbf{2 0 0 8}$ & 102.029 .636 & 93.946 .726 & 5.426 .644 & 2.656 .266 & 8.082 .910 \\
\hline $\mathbf{2 0 0 9}$ & 189.793 .936 & 175.708 .798 & 10.518 .377 & 3.566 .761 & 14.085 .139 \\
\hline $\mathbf{2 0 1 0}$ & 255.576 .891 & 239.483 .885 & 12.721 .931 & 3.371 .074 & 16.093 .005 \\
\hline $\mathbf{2 0 1 1}$ & 308.138 .048 & 291.517 .294 & 12.609 .493 & 4.011 .261 & 16.620 .754 \\
\hline $\mathbf{2 0 1 2}$ & 402.531 .203 & 378.639 .458 & 19.128 .244 & 4.763 .501 & 23.891 .745 \\
\hline $\mathbf{2 0 1 3}$ & 446.175 .217 & 415.546 .647 & 17.359 .717 & 13.268 .853 & 30.628 .571 \\
\hline
\end{tabular}

Tablo 6'da yer alan FTGK ve FiGK rakamları arasındaki fark tutarının 2007-2014 yılları arasındaki 8 yılı kapsayan toplamı 165.028.551 TL.'dir. 2006 yılı öncesi de dahil edildiği zaman bu rakam biraz daha büyüyecektir. FTGK tutarları fon varlığından indirildiği ve indirildikten sonra katılma belgesi fiyatları ilan edildiği için, fon getirileri hesaplanırken fark rakamına ayrıca dikkat edilmesine gerek yoktur. Ancak, emeklilik fonlarının toplam maliyeti ile ilgili yapılacak olan analizlerde FTGK ile FIGK arasındaki giderlerin de göz önünde bulundurulması gerekmektedir.

\footnotetext{
8 Örneğin OECD tarafından 2013 yılında hazırlanan "Pension Markets in Focus" raporunda, 2008-2012 yılları arasındaki 5 yıllık süreçte, Türkiye için oluşan reel getirilerin geometrik ortalaması \%3,4 olarak verilirken, çalışmada kullanılan yöntem sonucu 5 yıllık geometrik ortalama $\% 3,3$ olarak hesaplanmıştır.
} 


\subsection{Veri Analizi}

\subsubsection{FTGK Değişimi Analizi}

Aşağıda yer alan Grafik 1'de, 2008-2014 dönemi arasında, hem nominal rakamlar ile hem de fon aktifinden kesilen FTGK tutarlarının, fon aktif büyüklüğüne yüzdesel oranları yer almaktadır.

\section{Grafik 1: Yıllara Göre FTGK ${ }^{9}$ Değişimi}

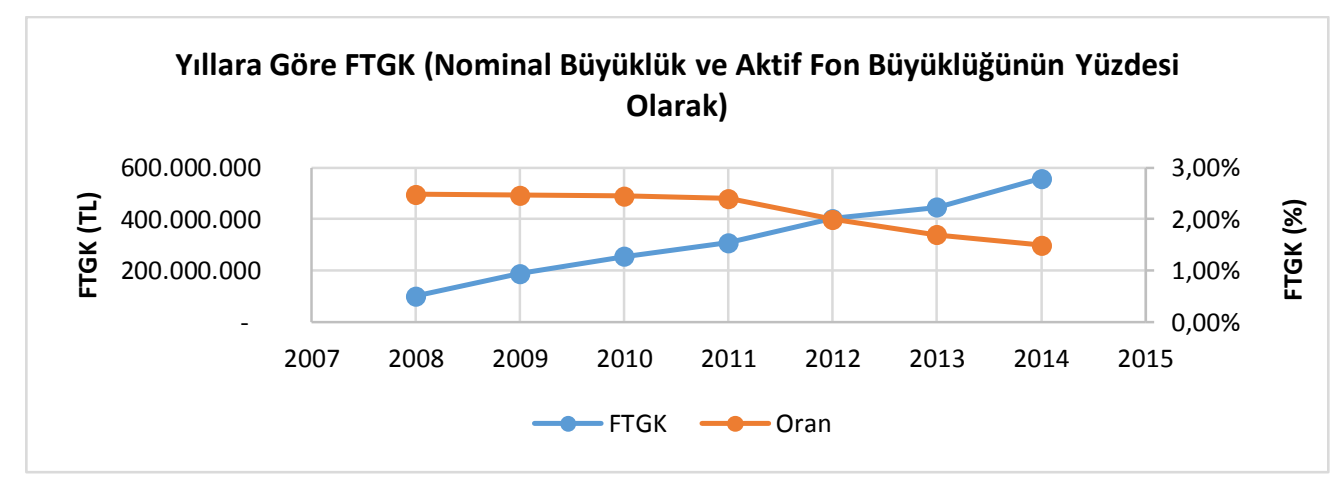

Görüldüğü üzere oransal olarak tahsil edilen FTGK tutarları sürekli olarak düşüş trendindedir. 2013 yılı öncesi uygulamada, fon aktif değeri üzerinden yapılabilecek fon işletim gideri kesintisi fonlar arasında herhangi bir ayrım yapılmadan, yıllık \%3,65 olarak belirlenmişken, bu mevzuata tabi son uygulama yılı olan 2012 yılında FTGK oranı \% 2 olarak gerçekleşmiş, sonrasında fon türleri itibariyle FTGK daha da düşmüş ve 2014 yılı itibari ile bu tutar \%1,5'lerin de altına inmiştir.

Ancak, her ne kadar oransal olarak bir düşüş mevcut olsa da tahsil edilen toplam nominal FTGK rakamları, fon aktif büyüklükleri hızla arttığı için, giderek büyümektedir. Örneğin devlet katkısı teşvikinin başladığı 2013 yılında fon toplam değeri \%24 artarken, tahsil edilen FTGK tutarı \% 10,8 artmış, 2014 yılında ise fon toplam değeri \%38 artarken, tahsil edilen FTGK tutarı \% 24,9 artmış, yeni sistemin uygulanmaya başlandığı 2 yıl içerisinde ise toplam değerdeki değişim \%72 iken, FTGK nominal tutar artışı \% 38,4 olarak gerçekleşmiştir. Dolayısıyla büyük ölçüde \%25 gibi yüksek bir oranda ve sisteme dahil olan herkesi kapsayan (vergi mükellefliği vs. gibi şartlara bakılmadan) bir kamu teşviği ile büyüyen bir sistemde, FTGK'ndeki oransal düşüş, sistemdeki gider miktarının artışına engel olamamaktadır.

\subsubsection{Toplam Gider Yapısının ve Gider Kalemlerinin Dağıımlarının Analizi}

Aşağıda yer alan grafik 2'de, 2008-2014 dönemi arasında, yıllık toplam kesintiler ile bu kesintilerin gider türlerine göre dağılımının yıllar itibarı ile değişimi yer almaktadır.

\footnotetext{
9 Rakamlar ve oranlar yazar tarafından, SPK internet sitesinde yer alan ve fon aktif değeri üzerinden yapılan tüm kesintilerin (fon yönetim giderleri, alım satım komisyonları, ihraç izni giderleri, tescil ve ilan giderleri, sigorta ücretleri, noter harç ve tasdik giderleri, bağımsız denetim ücreti, katılma belgesi basım giderleri, saklama ücreti, alınan kredi faizi, vergi, resim, harç vb. gibi giderler) yıllık olarak toplanmasından sonra hesaplanmıştır.
} 


\section{Grafik 2: Toplam Yıllık Kesintiler ve Kesintilerin Dağılımı (2008-2014) ${ }^{10}$}

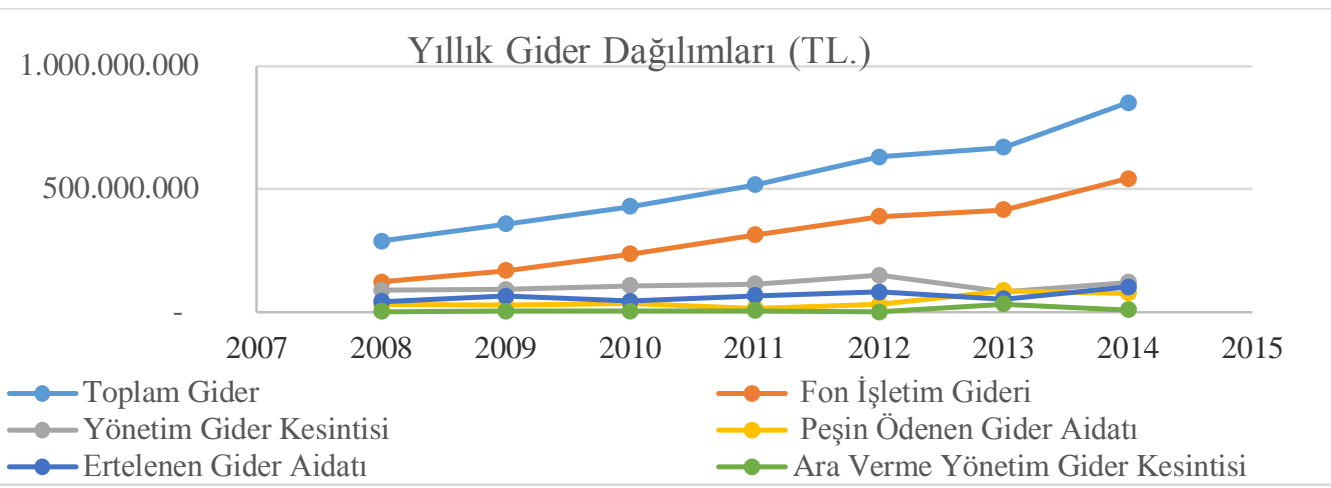

Grafik 2'den da görüldüğü üzere 2008 yılından itibaren toplam fon kesintilerinde nominal rakam bazında önemli bir artış görülmekte, ancak bu artışın temel sebebi, yönetim gider kesintisi, ara verme yönetim gideri kesintisi, ertelenen giriş aidatı, peşin ödenen giriş aidatı gibi diğer kalemlerdeki artıştan çok, esas olarak fon işletim gider kesintisi tutarlarındaki artıştan kaynaklanmaktadır.

Aşağıda yer alan Grafik 3'den de gider rakamları içerisinde en yüksek paya sahip olan fon işletim gideri payının, daha da yükselmesine ilişkin trend görülmektedir.

\section{Grafik 3: Yıllık Ücret Kalemlerinin Yüzdesel Dağılımı ${ }^{11}$}

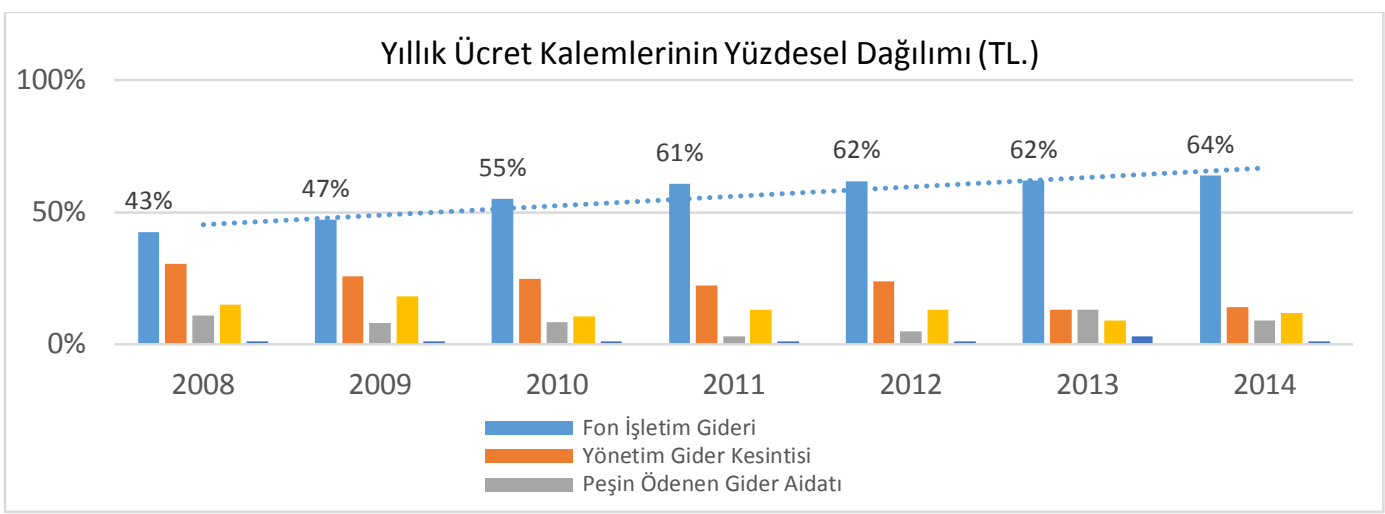

TGK'nin ve fon işletim giderlerinin her gün ve sürekli olarak artan aktif büyüklüğün belirli bir oranı olarak alındığı, 2013 yılı sonrası düzenlemeler ile hem ertelenmiş fon giriş aidatının sistemde kalma süresi arttıkça düşeceği, hem de devlet katkısı tutarının sistemde kalma süresi uzadıkça artmasına ilişkin düzenlemeler dikkate alındığında, FiGK'ndeki bu artışın önümüzdeki dönemlerde de devam etmesi kaçınılmazdır.

Diğer yandan FIGK rakamı veya oranı "veri temini” bölümünde de bahsedildiği üzere bir çok veri tabanında bulunan ve karşılaştırma yapma imkanı veren, bu anlamda da kullanıcıların rahatlıkla ulaşabileceği büyüklüklerdendir. Ancak bu rakamın dışında; yönetim gider kesintisi, ara verme yönetim gideri kesintisi, ertelenen giriş aidatı, peşin ödenen giriş aidatı gibi gider kalemlerinin de sağlıklı bir analiz yapılabilmesi için

\footnotetext{
10 Grafiğe baz olan rakamlar, yazar tarafından 2007-2014 yılları arasındaki yıllık BESGR'nda yer alan kümülatif rakam ve oranlardan yola çıkılarak "veri temini" bölümünde bahsedilen yöntem kullanılarak hesaplanmıştır. Ancak BESGR'de FTGK oranına yer verilmemekte, FIGK oranına yer verilmektedir. 2013-2014 yılı için SPK internet sitesinde yer alan oranlar dikkate alındığında FiGK, FTGK'nin \%93-\%94'ünü oluşturmakta, \%6, \%7 civarındaki alım satım komisyonu, saklama vs. gibi giderler yıllık BESG raporlarında gösterilmediği için analiz içinde de yer almamaktadır.

11 Grafiğe baz olan rakamlar, yazar tarafından 2007-2014 yılları arasındaki yıllık BESGR'nda yer alan kümülatif rakam ve oranlardan yola çıkılarak "veri temini” bölümünde bahsedilen yöntem kullanılarak hesaplanmıştır.
} 
bilinmesi ve hesaplamalara dahil edilmesi gerekmektedir. Ayrıca fon varlığını azaltan FTGK rakamı içerisinde, FiGK dışında kalan alım satım komisyonları, saklama ücretleri, ihraç izni giderleri gibi FiGK rakamına dahil olmayan giderler de yer almaktadır. Ancak ister FiGK olsun ister FTGK olsun ikisinin de her gün fon varlığından kesildiği ve dolayısıyla ilan edilen fon fiyatlarının da bu kesintileri yansıttığı, ayrıca önceki mevzuatta FiGK sonraki mevzuatta FTGK ifadelerine yer verildiği ve EGM tarafından sektöre ilişkin ilan edilen kümülatif gider dağılımlarında halen FiGK verisi kullanıldığı dikkate alınarak, bundan sonraki tablo ve grafiklerde fon varlığını azaltan gider kalemleri için FiGK kavramı kullanılacaktır.

Aşağıda yer alan Tablo 7'de yıllık bazda, FiGK, FiGK dışındaki gider kalemlerinin yüzdesi "W" ${ }^{12}$ (toplam giderFiGK) ve toplam gider ${ }^{13}$ kalemlerinin, değerlendirilen aktif büyüklük karşısındaki yüzdeleri ile FiGK ve W'nin toplam giderler içindeki yüzdesi yer almaktadır.

Tablo 7: BES Katılımcılarının Yıllık Bazda Gider Yükü ${ }^{14}$

\begin{tabular}{|c|c|c|c|c|c|}
\hline Yıl & FiGK & $\begin{array}{c}\text { W (Toplam } \\
\text { Gider-FiGK) }\end{array}$ & Toplam Gider & $\begin{array}{c}\text { FiGK/Toplam } \\
\text { Gider }\end{array}$ & $\begin{array}{c}\text { Diger Giderler/ Toplam } \\
\text { Gider }\end{array}$ \\
\hline $\mathbf{2 0 0 8}$ & $2,48 \%$ & $3,35 \%$ & $5,83 \%$ & $42,54 \%$ & $57,46 \%$ \\
\hline $\mathbf{2 0 0 9}$ & $2,46 \%$ & $2,76 \%$ & $5,22 \%$ & $47,10 \%$ & $52,90 \%$ \\
\hline $\mathbf{2 0 1 0}$ & $2,45 \%$ & $1,99 \%$ & $4,44 \%$ & $55,11 \%$ & $44,89 \%$ \\
\hline $\mathbf{2 0 1 1}$ & $2,40 \%$ & $1,55 \%$ & $3,95 \%$ & $60,70 \%$ & $39,30 \%$ \\
\hline $\mathbf{2 0 1 2}$ & $2,00 \%$ & $1,24 \%$ & $3,24 \%$ & $61,65 \%$ & $38,35 \%$ \\
\hline $\mathbf{2 0 1 3}$ & $1,70 \%$ & $1,04 \%$ & $2,74 \%$ & $61,94 \%$ & $38,06 \%$ \\
\hline $\mathbf{2 0 1 4}$ & $1,49 \%$ & $0,85 \%$ & $2,34 \%$ & $63,83 \%$ & $36,17 \%$ \\
\hline
\end{tabular}

Görüldüğü üzere FiGK dışında yer alan "diğer gider kalemleri” toplamı yıllar itibari ile giderek düşüyor olmakla birlikte, en düşük değeri aldığı 2014 yılında dahi, toplam giderlerin \%36'sının üzerinde bir pay almıştır. Dolayısıyla maliyet hesaplamalarında sadece FiGK'nin dikkate alınması yeterli olmamakta, tüm maliyetlerin hesaplamalara dahil edilmesi gerekmektedir.

\subsubsection{Fon Giderleri ile Reel Getirilerin Karşılaştırılması}

En basit anlamda, fon yönetiminin temel amacının uygun risk karşılığında getiri elde etmek olması ve bu temel amacı karşılamak için de bir ücret ödendiği düşünülürse, alınan ücretler ile yönetilen fonların getirilerinin karşılaştırılması gerekmektedir. Aşağıda yer alan Tablo 8'de, "veri temini" kısmında da anlatılan yöntem kullanılarak oluşturulmuş olan, "nominal getiri, reel getiri, ortalama reel getiri (geometrik), toplam gider rakamı ile FiGK farkı, tüm giderler düşüldükten sonra elde edilen reel getiri ve tüm giderler düşüldükten sonra elde edilen reel getirinin 2008-2012 yılları arasındaki geometrik ortalaması yer almaktadır. Tüm giderler düşüldükten sonra elde edilen reel getiri rakamı, fon getirilerinin FiGK düşüldükten sonra açıklandığı dikkate alınarak, FiGK dışında kalan giderlerin de (W) ilave olarak, getiri rakamlarından düşülmesi sonucu elde edilmiştir.

\footnotetext{
12 Grafiğe baz olan rakamlar, yazar tarafından 2007-2014 yılları arasındaki yıllık BESGR'nda yer alan kümülatif rakam ve oranlardan yola çıkılarak "veri temini" bölümünde bahsedilen yöntem kullanılarak hesaplanmıştır.

13 FiGK, yönetim gider kesintisi, ara verme yönetim gideri kesintisi, ertelenen giriş aidatı, peşin ödenen giriş aidatı rakamları toplanarak hesaplanmıştır.

14 Burada önemli bir hususu daha belirtmek gerekir ki yönetim gideri kesintisi gibi plan bazında yapılan kesintiler fonda yatırıma yönlendirilseydi ve kesinti oradan yapılsaydı etkileri daha az olacaktı.
} 
Tablo 8: Reel Getiriler, Giderlerden Sonra Kalan Reel Getiriler

\begin{tabular}{|c|c|c|c|c|c|c|c|}
\hline Yıl & $\begin{array}{c}\text { Nominal } \\
\text { Getiri }\end{array}$ & $\begin{array}{c}\text { Enflasyon } \\
\text { (TÜFE) }\end{array}$ & $\begin{array}{l}\text { Reel } \\
\text { Getiri }\end{array}$ & $\begin{array}{c}\text { Ortalama } \\
\text { Reel Getiri } \\
\text { (Geometrik) }\end{array}$ & $\begin{array}{c}\text { W } \\
\text { (Toplam Gider - } \\
\text { FiGK) }\end{array}$ & $\begin{array}{l}\text { Tüm Giderler } \\
\text { Düşüldükten } \\
\text { Sonra Reel Getiri }\end{array}$ & $\begin{array}{c}\text { Tüm Giderler } \\
\text { Düşüldükten Sonra } \\
\text { Yıllık Ortalama Reel } \\
\text { Getiri }\end{array}$ \\
\hline 2008 & $10,64 \%$ & $10,06 \%$ & $0,53 \%$ & $2,01 \%$ & $3,35 \%$ & $-2,82 \%$ & $0,19 \%$ \\
\hline 2009 & $21,64 \%$ & $6,53 \%$ & $14,18 \%$ & $2,01 \%$ & $2,76 \%$ & $11,42 \%$ & $0,19 \%$ \\
\hline 2010 & $9,31 \%$ & $6,40 \%$ & $2,73 \%$ & $2,01 \%$ & $1,99 \%$ & $0,74 \%$ & $0,19 \%$ \\
\hline 2011 & $-0,73 \%$ & $10,45 \%$ & $-10,12 \%$ & $2,01 \%$ & $1,55 \%$ & $-11,68 \%$ & $0,19 \%$ \\
\hline 2012 & $17,68 \%$ & $6,16 \%$ & $10,86 \%$ & $2,01 \%$ & $1,24 \%$ & $9,61 \%$ & $0,19 \%$ \\
\hline 2013 & $-0,98 \%$ & $7,40 \%$ & $-7,80 \%$ & $2,01 \%$ & $1,04 \%$ & $-8,84 \%$ & $0,19 \%$ \\
\hline 2014 & $14,81 \%$ & $8,17 \%$ & $6,14 \%$ & $2,01 \%$ & $0,85 \%$ & $5,29 \%$ & $0,19 \%$ \\
\hline
\end{tabular}

Aşağıda yer alan Grafik 4'de yıllar itibari ile; "FiGK", FIGK ve diğer giderlerin toplamı ile bulunan "toplam gider", "FiGK düşüldükten sonra yıllık reel getiri" ve son olarak da "tüm giderler düşüldükten sonra yıllık reel getiri" rakamları yer almaktadır.

\section{Grafik 4: Giderler ve Reel Getiriler}

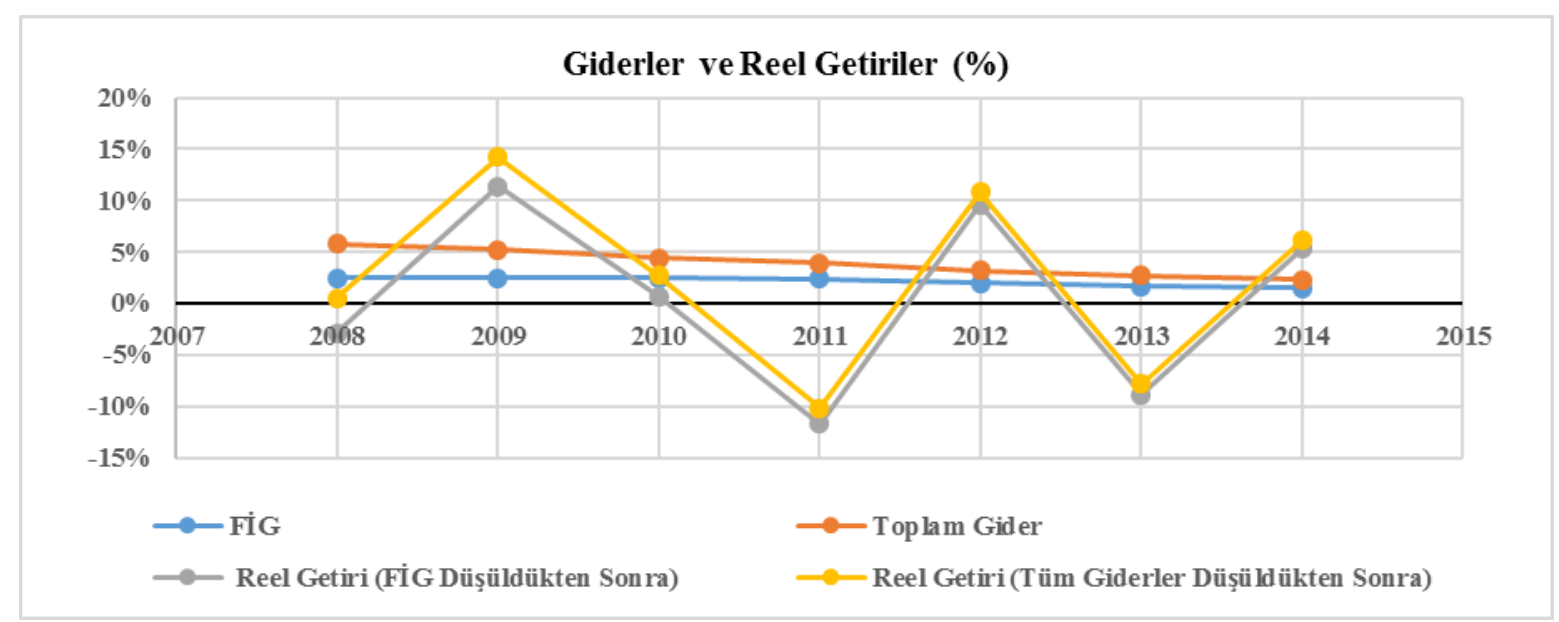

Grafik4'den de görülebileceği üzere 2008-2014 yılları arasında gider oranlarında sürekli bir düşüş trendi mevcutken, reel getiriler çok fazla değişkenlik göstermiş, örneğin "FiGK düşüldükten sonraki reel getiri" rakamı \% -10,12 ile \% 14,18 arasında gerçekleşmiştir. Bu nedenle giderler ile reel getiriler arasındaki ilişkiyi daha iyi görebilmek için, getirilerin 7 yıllık geometrik ortalaması ile yıllık gider yüzdelerinin yer aldığı Grafik 5 aşağıda verilmektedir. 
Grafik 5: Giderler ve Ortalama (Geometrik) Reel Getiriler

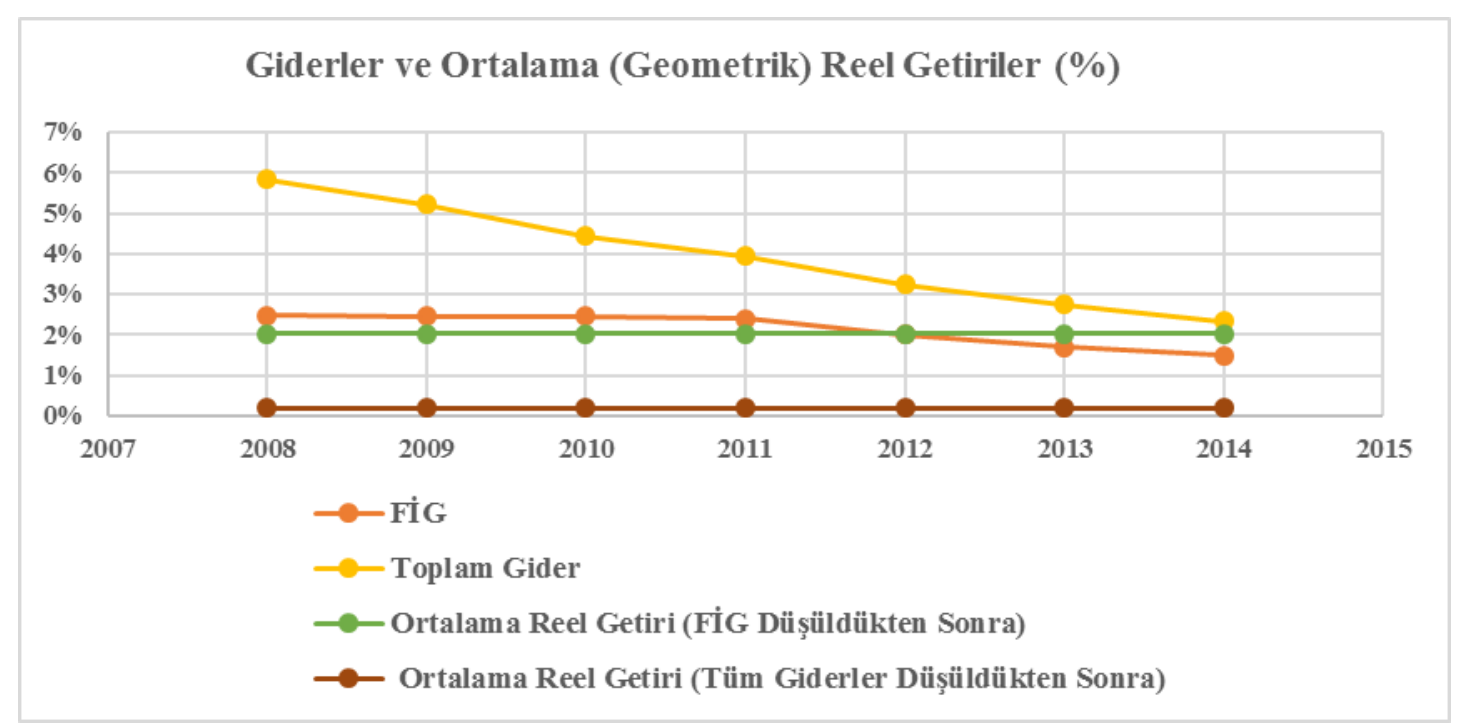

Grafikten 5'den de görülebileceği üzere sadece FiGK göz önünde bulundurulduğunda katılımcıların ortalama reel getirisi, (\% 2.01) iken, FiGK dışındaki diğer giderlerin de indirilmesi durumunda ortalama reel getiri \% 0,19'a düşmektedir. Bunun karşılığında tahsil edilen toplam ücretler ise inceleme dönemi olan 2008-2014 yılları arasında sürekli olarak düşmüş, 2008'de sektörün toplam gider rakamı \%5,83 iken, 2014 yılı itibariyle bu rakam \%2,34'e düşmüştür. Ancak ücretlerin en fazla düştüğü 2014 yılında bile, toplam \%2,34 oranında toplam kesinti yapılırken, karşılığında tüm giderlerden arındırılmış ortalama reel getiri oranı \% 0,19 olarak gerçekleşmiştir.

\section{DEĞERLENDIRME VE SONUÇ}

Bireysel emeklilik sistemi üzerindeki giderler mevzuat ile FTGK, peşin ödenen giriş aidatı, yönetim ve ara verme gider kesintileri toplamı olarak belirtilmekte, FTGK içinde de fondan yapılan kesintileri ifade eden FiGK, fon yönetim ücreti ve ertelenmiş gider aidatı, aracılık komisyonları gibi farklı gider tanımlamaları da bulunmaktadır. Bu giderlerden peşin ödenen giriş aidatı, yönetim ve ara verme gider kesintileri ve ertelenmiş gider aidatları yatırımlar henüz bireysel emeklilik fonlarına yönlendirilmeden emeklilik planı dahilinde kesilmekte; tamamı FTGK başlığı altında incelenebilecek olan, FiGK, aracılık komisyonları, saklama ücreti gibi bazı giderler de katılımlar emeklilik fonlarına yönlendirildikten sonra fon varlığı üzerinden kesilmektedir. Bu nedenle birinci grup giderleri "plan kapsamında yapılan kesintiler", ikinci grup giderleri de "fon varlığını azaltan giderler" olarak nitelendirmek mümkündür.

BES üzerinde karşılaştırma imkanı sağlayan toplu veriler "fon varlığını azaltan giderler" olmakta, bu gider kalemleri oransal olarak her yıl düşmekte, ancak bu oransal düşmeye karşılık yönetilen portföy tutarı daha fazla arttığı için sistem üzerinden toplamda tahsil edilen ücretler yükselmekte, toplam tahsil edilen ücretler içerisinde FiGK'nin payı her yıl artmakta, ancak halen ücretlerin üçte birinden fazlasını oluşturan "plan kapsamında yapılan kesintiler", ile ilgili verilere kolayca erişilememektedir.

Diğer yandan BES katılımcılarının bu giderlere katlanmalarının ana sebebi alınan riske göre belirli bir getiri elde etmek ve emeklilik dönemlerinde refah düzeylerini arttıracak bir birikim sağlamak olarak tanımlanabilecekken, 2008-2014 dönemi arasında emeklilik planları ortalama olarak \%0,19 oranında bir reel getiri elde etmekte, bir başka deyişle masraflar düşüldükten sonra ancak birikimleri enflasyon karşısında eritmeyecek kadar bir gelir edilebilmektedir. Ancak bu getiri karşılığında ise kesintilerin en düşük olduğu 2014 yılında dahi çeşitli kalemler adı altında \%2,34 oranında kesinti yapılmıştır. Tuesta (2015) tarafından yapılan ve 53 ülkenin dikkate alındığı çalışmada ortalama maliyetler \% 1.14 olarak hesaplanmış, kesintilerin en düşük olduğu ülke ise 2008 yılındaki \% 0.016 oranı ile Norveç olmuştur. Dolayısı ile hem en iyi ülke uygulamaları hem de Dünya ortalamaları dikkate alındığında, yıllar boyunca düşüş trendinde olmasına rağmen, halihazırda Türkiye'de uygulanan kesinti tutarları yüksektir. 
IOPS (2014, s.18) tarafından Türkiye'nin ortalama kesinti oranının \%2 olduğu varsayımı ile yapılan hesaplamada, sistemde 40 yıl kalan bir yatırımcının alacağı birikim tutarı, hiç kesinti yapılmaması durumuna göre \%39.59 oranında azalacağı sonucuna ulaşılmıştır. Sistemde kalma süresi 30 yıla düşerse bu kesinti tutarı \%30.25'e, sistemde kalma süresi 20 yıla düşerse de birikimlerdeki azalma oranı \% 20.36'ya düşmektedir. Diğer tüm kesintiler hesaba katılarak 2014 yılı için hesaplanan \%2,34 rakamının sürekli olarak devam edeceği ve her yıl diğer giderlerin katılarak bulunan bu ortalamanın devam edeceği varsayılır ise sistemde 40 yıl kalınması durumunda emeklilik birikimindeki azalma \% 44 civarında olacaktır. Bu reel getiri ve gider tablosu karşısında BES sistemine dahil olmak için çok güçlü bir teşvik gerekmekte, kamu katkısı da bu motivasyonu sağlamaktadır.

BES uygulamasının başlangıcında halkın bu konuda yeteri kadar bilgi sahibi olmaması, şirketlerinin yeni kurulmuş olması ve kuruluş maliyetlerinin yüksekliği, yeni bir sistemin tanıtılması için gerekli olan satış ve pazarlama giderlerinin yüksek olması, sistemdeki katılımcı sayısının ve yönetilen fon tutarlarının azlığı gibi sebeplerle kesintilerin yüksek olması normal olarak kabul edilebilir. Hatta hızlı bir şekilde katılımcı sayısının arttırılabilmesi için şirketlerin ve acentaların teşvik edilmesi amacıyla bu uygulamaya izin verilmiş de olabilir. Ancak katılımc sayısının 6 milyonu, Devlet katkı payı dahil olmak üzere yönetilen fon tutarının da 50 milyar TL’nı aştığı ve reel getirilerin azaldığı bir ortamda mevcut gider yapısının sürdürülemez olduğu açıktır.

BES üzerinden yapılan kesintiler çalışma dönemi olan 2008-2014 yılları arasında oransal olarak sürekli düşmüş, 2008'de sektörün toplam gider rakamı \%5,83 iken, 2014 yılı itibariyle bu rakam \%2,34'e düşmüştür.

Bu kapsamda yüksek kesinti tutarlarının indirilebilmesi için hem Türkiye'deki gelişmeler hem de dünyadaki iyi ülke uygulamaları dikkate alınarak bazı yöntemler uygulanabilir. Hali hazırda Türkiye'de de uygulanan düzenlemeler ile üst limit belirlenmesi uygulaması etkin, ancak tek başına yeterli değildir. Sorunun çözümü için bireysel imzalanan sözleşmelere kıyasla, giderlerin çok daha düşük olduğu grup veya işveren emeklilik planlarının paylarının arttırı masının teşvik edilmesi, internet üzerinden ya da çağrı merkezi gibi daha az masraflı pazarlama kanallarının kullanımının arttırıması, otomatik katılım uygulamasının başlaması, emeklilik şirketlerinin ana işlevlerinin satış pazarlama ve katılımcı için plan oluşturmak olduğu, fon kurucusu olamadığı sistemlerin incelenmesi, portföy yönetim şirketleri, emeklilik şirketleri ve acenta bankaların büyük ölçüde aynı finansal grup içinde bulunmalarından kaynaklanan maliyeti arttırıcı problemlerin çözülmesi gibi konular üzerinde çalışıımasında fayda vardır.

Ayrıca var olan karmaşık gider yapısının yatırımcılara ne şekilde aktarılabileceğine ve tüm emeklilik planlarına ilişkin her türlü gider verisinin katılımcı olmayı düşünenlere veya mevcut katılımcılara kolay anlaşılabilir bir şekilde sunulması da sistem katılımcılarının doğru karar vermelerine yardımcı olacaktır. 


\section{KAYNAKÇA}

Bikker, J. A., Onno, S. ve Torracchi W., F. 2012, "The Impact of Scale, Complexity and Service Quality on the Administrative Costs of Pension Funds: A Cross-Country Comparison" The Journal of Risk and Insurance, Vol. 79, No. 2, 477-514

Bireysel Emeklilik Tasarruf ve Yatırım Sistemi Kanunu. 2001, T. C. Resmi Gazete, 24366, 07 Nisan 2001

Calveley, M. 2015, The Cap of DC Scheme Charges, Londra: KPMG LLP.

Emeklilik Gözetim Merkezi. 2006, “Bireysel Emeklilik Sistemi 2005 Gelişim Raporu” http://www.egm.org.tr/bes2005gr.asp, (02 Temmuz 2015)

Emeklilik Gözetim Merkezi. 2007, “Bireysel Emeklilik Sistemi 2005 Gelişim Raporu” http://www.egm.org.tr/bes2006gr.asp, (03 Temmuz 2015)

Emeklilik Gözetim Merkezi. 2008, "Bireysel Emeklilik Sistemi 2005 Gelişim Raporu" http://www.egm.org.tr/bes2007gr.asp, (03 Temmuz 2015)

Emeklilik Gözetim Merkezi. 2009, "Bireysel Emeklilik Sistemi 2005 Gelişim Raporu” http://www.egm.org.tr/bes2008gr.asp, (03 Temmuz 2015)

Emeklilik Gözetim Merkezi. 2010, “Bireysel Emeklilik Sistemi 2005 Gelişim Raporu” http://www.egm.org.tr/bes2009gr.asp, (03 Temmuz 2015)

Emeklilik Gözetim Merkezi. 2011, “Bireysel Emeklilik Sistemi 2005 Gelişim Raporu” http://www.egm.org.tr/bes2010gr.asp, (03 Temmuz 2015)

Emeklilik Gözetim Merkezi. 2012, “Bireysel Emeklilik Sistemi 2005 Gelişim Raporu” http://www.egm.org.tr/bes2011gr.asp, (04 Temmuz 2015)

Emeklilik Gözetim Merkezi. 2013, “Bireysel Emeklilik Sistemi 2005 Gelişim Raporu” http://www.egm.org.tr/bes2012gr.asp, (03 Temmuz 2015)

Emeklilik Gözetim Merkezi. 2014, “Bireysel Emeklilik Sistemi 2005 Gelişim Raporu” http://www.egm.org.tr/bes2013gr.asp, (04 Temmuz 2015)

Emeklilik Gözetim Merkezi. 2015a, http://www.egm.org.tr/weblink/BESgostergeler.asp, (01 Mart 2016)

Emeklilik Gözetim Merkezi. 2015b, “Bireysel Emeklilik Sistemi 2005 Gelişim Raporu” http://www.egm.org.tr/bes2014gr.asp, (03 Temmuz 2015)

Hernandez, D.G. ve Stewart, F. 2008, “Comparison of Costs Fees In Countries With Private Defined Contribution Pension System: Working Paper No. 6. IOPS, Paris

Ionescu, L. ve Robles, E. A. 2014, “Update of IOPS Work on Fees and Charges" IOPS Working Papers on Effective Pensions Supervision, No: 20. IOPS, Paris

KAP (2015) http://www.kap.gov.tr/yatirim-fonlari/yatirim-fonlari-bilgi-formu.aspx?madde_no=1043\& durum_=1\&eyf_=1 (14.10.2015)

Mitchell, O. 1998, "Administrative Costs In Public And Private Retirement Systems: Privatizing Social Security" University of Chicago Press, Chicago, IL

OECD 2013, “Pensions at a Glance 2013: OECD and G20 Indicators” Paris: OECD.

Pitt-Watson, D. 2010, “Tomorrow's Investor: Building the consensus for a People's Pension in Britain", London:FRSA

TBMM. 2012, Bireysel Emeklilik Tasarruf ve Yatırım Sistemi Kanununda Değişiklik Yapılmasına Dair Kanun Teklifi ile Plan ve Bütçe Komisyonu Raporu,

TBMM. 2015, https://www.tbmm.gov.tr/sirasayi/donem24/yil01/ss271.pdf (20 Kasım 2015)

TEFAS, 2015, http://www.fonturkey.com.tr/FonKarsilastirma.aspx (17.10.2015)

Tuesta, D. 2014, "Factors Behind the Administrative Fees of Private Pension Systems: An International Analysis" Journal of Pension Economics and Finance, , Vol. 13, Issue 01, 88-111

Turner, A. 2005, "Turner Report, A New Pension Settlement for the Twenty-First Century, The Second Report of the Pensions Commission", The Stationary Office

Whitehouse, E. 2000a, "Paying For Pensions: An International Comparison Of Administrative Charges in Funded Retirement-Income Systems" Financial Services Authority, London.

Whitehouse, E. 2000b, "Administrative Charges for Funded Pensions : An International Comparison and Assessment" Social Protection Discussion Paper No. SP 16 Washington, D.C.: The World Bank.

Yazıcı, S. 2015, “Bireysel Emeklilik Sitemi ve Türkiye Uygulaması” Yayınlanmamış Doktora Tezi, Ankara, A.Ü. Sosyal Bilimler Enstitüsü. 